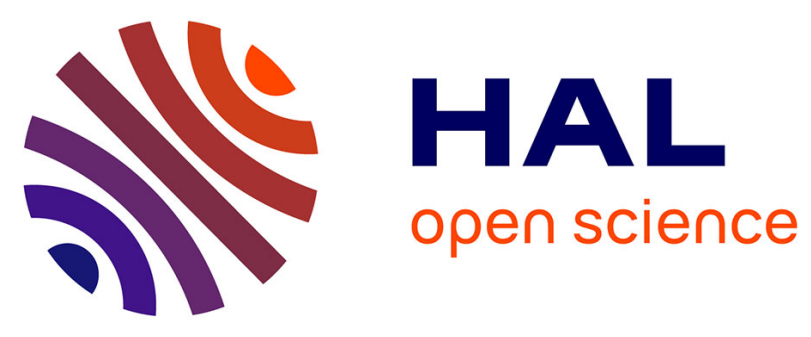

\title{
Revelation on the complex nature of mesoporous hierarchical FAU-Y zeolites
}

\author{
Dirk Mehlhorn, Jeremy Rodriguez, Thomas Cacciaguerra, Radu-Dorin \\ Andrei, Claudia Cammarano, Flavien Guenneau, Antoine Gedeon, Benoit \\ Coasne, Matthias Thommes, Delphine Minoux, et al.
}

\section{To cite this version:}

Dirk Mehlhorn, Jeremy Rodriguez, Thomas Cacciaguerra, Radu-Dorin Andrei, Claudia Cammarano, et al.. Revelation on the complex nature of mesoporous hierarchical FAU-Y zeolites. Langmuir, 2018, 34 (38), pp.11414-11423. 10.1021/acs.langmuir.8b03010 . hal-01897060

\section{HAL Id: hal-01897060 \\ https://hal.sorbonne-universite.fr/hal-01897060}

Submitted on 16 Oct 2018

HAL is a multi-disciplinary open access archive for the deposit and dissemination of scientific research documents, whether they are published or not. The documents may come from teaching and research institutions in France or abroad, or from public or private research centers.
L'archive ouverte pluridisciplinaire HAL, est destinée au dépôt et à la diffusion de documents scientifiques de niveau recherche, publiés ou non, émanant des établissements d'enseignement et de recherche français ou étrangers, des laboratoires publics ou privés. 


\section{Revelation on the complex nature of mesoporous hierarchical FAU-Y zeolites}

Dirk Mehlhorn, ${ }^{1}$ Jeremy Rodriguez, ${ }^{1}$ Thomas Cacciaguerra, ${ }^{1}$ Radu-Dorin Andrei, ${ }^{1}$ Claudia Cammarano, ${ }^{1}$ Flavien Guenneau, ${ }^{2}$ Antoine Gedeon, ${ }^{2}$ Benoit Coasne, ${ }^{3}$ Matthias Thommes, ${ }^{4}$ Delphine Minoux,${ }^{5}$ Cindy Aquino, ${ }^{5}$ Jean-Pierre Dath,${ }^{5}$ François Fajula, ${ }^{1}$ Anne Galarneau ${ }^{1 *}$

${ }^{1}$ ICGM UMR 5253 CNRS - Univ Montpellier - ENSCM, ENSCM 240 Av Pr E. Jeanbrau, 34296 Montpellier cedex 5, France.

${ }^{2}$ Sorbonne Université, CNRS, Collège de France, Laboratoire de Chimie de la Matière Condensée, LCMCP, F-75005 Paris, France.

${ }^{3}$ Laboratoire Interdisciplinaire de Physique (LIPhy), CNRS and University Grenoble Alpes, 140 rue de la Physique, Domaine Universitaire, BP 87, 38402 Saint Martin d'Heres Cedex.

${ }^{4}$ Quantachrome Instruments, 1900 Corporate Drive, Boynton Beach, Florida 33426, United States

${ }^{5}$ Total Research\&Technology Feluy, Belgium.

*E-mail: anne.galarneau@enscm.fr 
ABSTRACT: The texture of mesoporous FAU-Y (FAUmes) prepared by surfactanttemplating in basic media is a subject of debate. It is proposed that mesoporous FAU-Y consist of: 1- ordered mesoporous zeolite networks formed by a surfactant-assisted zeolite rearrangement process involving local dissolution and reconstruction of the crystalline framework, and, 2- ordered mesoporous amorphous phases as Al-MCM-41, which coexist with zeolite nanodomains obtained by a dissolution-reassembly process. By the present systematic study, performed with FAU-Y $(\mathrm{Si} / \mathrm{Al}=15)$ in the presence of octadecyltrimethylammonium bromide and $0<\mathrm{NaOH} / \mathrm{Si}$ ratio $<0.25$ at $115^{\circ} \mathrm{C}$ for $20 \mathrm{~h}$, we demonstrate that mesoporous FAU zeolites consist in fact in a complex family of materials with textural features strongly impacted by the experimental conditions. Two main families have been disclosed: 1 - for $0.0625<\mathrm{NaOH} / \mathrm{Si}<0.10$, FAUmes are ordered mesoporous materials with zeolite walls, which coexist with zeolite nanodomains $(100-200 \mathrm{~nm})$ and 2for $0.125<\mathrm{NaOH} / \mathrm{Si}<0.25$, FAUmes are ordered mesoporous materials with amorphous walls as Al-MCM-41, which co-exist with zeolite nanodomains $(5-100 \mathrm{~nm})$. The zeolite nanodomains are decreasing in size with the increase of $\mathrm{NaOH} / \mathrm{Si}$ ratio. Increasing $\mathrm{NaOH} / \mathrm{Si}$ ratio leads to an increase of mesopore volume, while total surface area remains constant, and to a decrease of strong acidity in line with the decrease of micropore volume. The ordered mesoporous materials with zeolite walls feature the highest acidity strength. The ordered mesoporous materials with amorphous walls present additional large pores $(50-200 \mathrm{~nm})$, which increase in size and amount with the increase of $\mathrm{NaOH} / \mathrm{Si}$ ratio. This alkaline treatment of FAU-Y represents a way to get ordered mesoporous materials with zeolite walls with high mesopore volume for $\mathrm{NaOH} / \mathrm{Si}=0.10$ and a new way to synthesize mesoporous Al-MCM-41 materials containing extra-large pores $(50-200 \mathrm{~nm})$ ideal for optimal diffusion $(\mathrm{NaOH} / \mathrm{Si}=$ $0.25)$.

Keywords: hierarchical materials, MCM-41, Faujasite, Zeolite Y, nitrogen adsorption, argon adsorption, acidity, mesoporous/macroporous materials 


\section{INTRODUCTION}

Microporous materials such as zeolites have strongly impacted the refining and petrochemical industries due to their unique properties such as crystallinity, high-surface area, acidity, ion-exchange capacity, molecular sieving and shape-selectivity. ${ }^{1}$ In catalysis however, the presence of micropores may impose internal diffusion limitations resulting in low catalyst effectiveness, pore clogging by large products or oligomers and ultimately coke formation and deactivation resulting in a decrease of productivity with time under continuous use. To increase the accessibility of the reactants to the active sites as well as the desorption of the products, creation of additional mesopores in zeolite crystals has been proposed. ${ }^{2-10}$ Most commonly, zeolites can be dealuminated to create large pores in the crystals, but these pores are inhomogeneous in size, often not directly connected to the exterior of the crystal and not forming a connected network inducing very low increase in diffusion, as usually assumed in the literature. ${ }^{11}$ Additional techniques have been used to further increase diffusion in zeolites such as desilication in basic medium leading to mesopores connected to the exterior but inhomogeneous in size. ${ }^{8-10}$ Homogeneity of mesopore diameter has been proven to enhance mass transport in purely mesoporous materials. ${ }^{12,13}$ In 2005 , a new procedure to synthesize mesoporous zeolites was applied by adding alkyltrimethylammonium bromide surfactants (CnTAB, $\mathrm{n}=10-22$ ) in basic medium to create FAU-Y zeolite with homogeneous ordered mesopores like in MCM-41 materials (Hereafter FAUmes). ${ }^{14,15}$ It was recently suggested that, depending on the experimental conditions used, two mechanisms could operate, leading to somewhat different materials, a dissolution-reassembly process ${ }^{7}$ or a surfactant-assisted zeolite rearrangement process a zeolite surfactant-templating process with only local dissolution. ${ }^{16-18}$ In the first case, the zeolite crystal is partially dissolved and the dissolved species reassemble around surfactant micelles leading to the formation of an ordered mesoporous phase with amorphous walls as Al-MCM-41 containing additional zeolite fragments whereas in the second case the zeolite framework is mesostructured by the surfactant micelles without dissolution, leading to a zeolite with intracrystalline ordered mesoporosity free of amorphous mesoporous material. The latter can be therefore seen as a MCM-41-type architecture of mesopores built with crystalline zeolite walls of FAU-Y. In term of mesopores ordering both materials present a MCM-41-type architecture, one with amorphous walls and the other with crystalline walls. The first case has also been described as composites of (hierarchical) zeolites with ordered mesoporous materials (OMMs). ${ }^{19,20}$

FAUmes feature homogeneous distributions of mesopores, due to the micelletemplated mechanism, and the interplay between the micropores and the mesopores has been proven by electron tomography ${ }^{21}$ and by determination of the diffusion coefficients of hexane measured by ${ }^{1} \mathrm{H}$ PFG NMR. ${ }^{22}$ Indeed, in mechanical mixtures of FAU-Y and MCM-41 powders (particles of ca. $10 \mu \mathrm{m}$ each) two ${ }^{1} \mathrm{H}$ PFG NMR signal decays have been obtained corresponding to the diffusion in the zeolite and in the mesoporous parts. On the contrary for FAUmes only one decay was observed with a hexane diffusion coefficient intermediate between the one in pure zeolite and the one in MCM- $41 .^{22}$

Different experimental conditions have been reported in the literature for the synthesis of FAUmes starting from zeolite crystals with various $\mathrm{Si} / \mathrm{Al}$ ratios, using several sources of alkali $\left(\mathrm{NaOH}, \mathrm{TMAOH}, \mathrm{NH}_{4} \mathrm{OH}\right)$, different temperatures $\left(80,115,150{ }^{\circ} \mathrm{C}\right)$, different durations (12 to $24 \mathrm{~h})$ and different types and amounts of alkyltrimethylammonium 
surfactants (CnTAX, $\mathrm{n}=10-22, \mathrm{X}=\mathrm{Cl}, \mathrm{Br}){ }^{4,14-24}$ In the present study, a systematic investigation of the materials resulting from the transformation of FAU-Y ( $\mathrm{Si} / \mathrm{Al}=15)$ into FAUmes has been performed. Materials have been prepared using $\mathrm{C} 18 \mathrm{TAB}$ as surfactant and $\mathrm{NaOH}$ as the alkali from mixtures with molar ratios $1 \mathrm{SiO}_{2} / n \mathrm{NaOH} / 0.1 \mathrm{C} 18 \mathrm{TAB} / 50 \mathrm{H}_{2} \mathrm{O}$ $(n=0.025-0.25)$ at $115{ }^{\circ} \mathrm{C}$ for $20 \mathrm{~h}$. Our aim was to analyze precisely their structural, textural and acidic properties as a function of $\mathrm{NaOH} / \mathrm{Si}$ ratio. Textural and structural properties of FAUmes have been analyzed by Transmission Electron Microscopy (TEM), XRay powder diffraction (XRD), nitrogen sorption at $77 \mathrm{~K}$ and t-plot method, ${ }^{25}$ Ar sorption at 77 and $87 \mathrm{~K}$ and by geometrical calculations using XRD and pore volumes, as previously done for SBA-15 materials. ${ }^{26,27}$ Acidity of FAUmes materials has been measured by Temperature Programmed Desorption (TPD) of ammonia.

\section{EXPERIMENTAL SECTION}

Synthesis of mesoporous FAU-Y (FAUmes). In a beaker $(250 \mathrm{~mL}), x \mathrm{~g}$ of $\mathrm{NaOH}$ pellets (Table 1) were added to $180 \mathrm{~g}$ of $\mathrm{H}_{2} \mathrm{O}$ and the mixture was stirred with a magnet until complete dissolution at $25{ }^{\circ} \mathrm{C}$. Then $7.843 \mathrm{~g}$ of octadecyltrimethylammonium bromide (C18TAB) were added under magnetic stirring until the complete dissolution at $25{ }^{\circ} \mathrm{C}$. The magnetic stirrer was then replaced by an endless screw stirrer, which gives a more gentle stirring, necessary to keep the particle size and shape of the initial material as evidenced for pseudomorphic synthesis of silica particles into MCM-41 particles. ${ }^{13}$ The parent zeolite (12 $\mathrm{g})$, dealuminated $\mathrm{H}^{+}$-FAU-Y $(\mathrm{Si} / \mathrm{Al}=15) \mathrm{CBV720}$ purchased from Zeolyst was then added to the preceding solution and stirred for $1-2 \mathrm{~h}$ at $25{ }^{\circ} \mathrm{C}$ until a homogeneous white suspension was obtained. The solid recovered was then transferred into a Teflon-lined stainless autoclave $(250 \mathrm{~mL})$ and left static for 20 hours at $115^{\circ} \mathrm{C}$. It was then filtered and washed with water until neutral $\mathrm{pH}$. The sample was then dried in an oven at $80{ }^{\circ} \mathrm{C}$ for $12 \mathrm{~h}$ and calcined at 550 ${ }^{\circ} \mathrm{C}$ for $8 \mathrm{~h}$ (heating rate $5 \mathrm{~K} / \mathrm{min}$ ). The molar ratios of the mixtures were calculated by approximating FAU-Y as $\mathrm{SiO}_{2}: 1 \mathrm{SiO}_{2} / 0.1 \mathrm{C} 18 \mathrm{TAB} / n \mathrm{NaOH} / 50 \mathrm{H}_{2} \mathrm{O}$ (Table 1).

Synthesis of mesoporous MCM-41. Same protocole as above was used to synthesize MCM-41 materials by replacing FAU-Y by fumed silica, Aerosil 200 purchased from Degussa.

Cationic exchange of $\mathrm{Na}^{+}$-FAUmes into $\mathrm{H}^{+}$-FAUmes for $\mathrm{NH}_{3}$ TPD measurements. $6.3 \mathrm{~g}$ of calcined $\mathrm{Na}^{+}-\mathrm{FAUmes}$ were put into $630 \mathrm{~mL} \mathrm{NH}_{4} \mathrm{NO}_{3} 0.1 \mathrm{M}$ in ethanol and heated under reflux at $90{ }^{\circ} \mathrm{C}$ for $1 \mathrm{~h}$, filtered and put again in a new solution of $\mathrm{NH}_{4} \mathrm{NO}_{3}$. This was repeated 3 times. After the third cationic-exchange the material was filtered and washed 3 times with $200 \mathrm{~mL}$ of absolute ethanol. The material was dried at $80{ }^{\circ} \mathrm{C}$ overnight to obtain $\mathrm{NH}_{4}{ }^{+}$-FAUmes and calcined at $450{ }^{\circ} \mathrm{C}$ for $6 \mathrm{~h}$ to obtain $\mathrm{H}^{+}$-FAUmes.

Materials Characterization. X-Ray Diffraction (XRD) patterns of the materials were collected using a Bruker D8 Advance diffractometer with a Bragg-Brentano geometry, equipped with a Bruker Lynx Eye detector and using $\mathrm{Cu} \mathrm{K} \alpha$ radiation and a Ni filter. XRD patterns were recorded in the range $4-50^{\circ}(2 \theta)$ to identify zeolite peaks and in the range 0.04 - $6^{\circ}$ to identify mesostructure organization. The angular step size was of $0.0197^{\circ}$ and the counting time of $0.2 \mathrm{~s}$ per step. 
Textural properties of the materials were determined by $\mathrm{N}_{2}$ adsorption/desorption isotherms at $77 \mathrm{~K}$ recorded on a Belsorb apparatus: $200-300 \mathrm{mg}$ of sample were used and outgassed under vacuum at $250{ }^{\circ} \mathrm{C}$ for $12 \mathrm{~h}$ before analysis. Broekhoff and De Boer (BdB) method was applied to the $\mathrm{N}_{2}$ desorption isotherm to calculate mesopore diameters, as previously recommended for MCM-41 materials. ${ }^{27}$ Micropore volumes were evaluated by corrected t-plot method. ${ }^{24} \mathrm{Ar}$ adsorption/desorption isotherms were performed at 77 and $87 \mathrm{~K}$ on an Autosorb-1C apparatus at Quantachrome: $50 \mathrm{mg}$ of sample were used and outgassed under vacuum at $200{ }^{\circ} \mathrm{C}$ for $20 \mathrm{~h}$ before analysis. Cumulative pore volume curves were drawn to calculate micropore volumes using NLDFT method with a spherical model for micropores and cylindrical model for mesopores.

Transmission electron microscopy (TEM) images were recorded using a JEOL 1200 EX2 microscope operating at $100 \mathrm{kV}$ at "Plateau Technique du Pole Chimie Balard Montpellier".

The acidic properties of initial $\mathrm{H}^{+}$-FAU-Y and $\mathrm{H}^{+}$-FAUmes were studied by Temperature-Programmed Desorption of ammonia ( $\mathrm{NH}_{3}$-TPD) using an AUTOCHEM 2910 apparatus from Micromeretics. The samples $(40 \mathrm{mg})$ were pre-treated at $550{ }^{\circ} \mathrm{C}$ under air flow $(30 \mathrm{~mL} / \mathrm{min})$ for $10 \mathrm{~min}$. After returning down to $100^{\circ} \mathrm{C}$ the samples were saturated with ammonia $(45 \mathrm{~mL} / \mathrm{min})$ coming from a mixture of $\mathrm{NH}_{3} / \mathrm{He}\left(5 \% \mathrm{NH}_{3}\right)$ at $100{ }^{\circ} \mathrm{C}$ for 30 min. The weakly adsorbed $\mathrm{NH}_{3}$ was removed by evacuation at $120{ }^{\circ} \mathrm{C}$ for $30 \mathrm{~min}$ in a dry helium stream $(25 \mathrm{~mL} / \mathrm{min})$. The ammonia desorption was carried out in helium stream (25 $\mathrm{mL} / \mathrm{min}$ ) at a heating rate of $10{ }^{\circ} \mathrm{C} / \mathrm{min}$ up to $600{ }^{\circ} \mathrm{C}$. The amount of desorbed ammonia was monitored with a thermal conductivity detector (TCD).

\section{RESULTS AND DISCUSSION}

Structural properties of FAUmes determined by XRD and TEM. Different mesoporous FAU-Y zeolites were synthesized using dealuminated $\mathrm{H}^{+}$-FAU-Y $(\mathrm{Si} / \mathrm{Al}=15)$ as starting material. The reaction consists of a pseudomorphic transformation (meaning that the particle morphology and size of the initial material is maintained during the tranformation) of FAU-Y into mesoporous FAU-Y (FAUmes) with MCM-41-like mesoporosity using octadecyltrimethyl ammonium surfactant $(\mathrm{C} 18 \mathrm{TAB})$ at different molar ratios of $\mathrm{NaOH} / \mathrm{Si}$ $(0.025<\mathrm{NaOH} / \mathrm{Si}<0.25)$. The resulting materials are under $\mathrm{Na}^{+}$form. Each material will be also referenced by its $\mathrm{NaOH} / \mathrm{Si}$ ratio in the synthesis.

For $0<\mathrm{NaOH} / \mathrm{Si}<0.05, \mathrm{XRD}$ pattern recorded at high angles (Figure 1) show the characteristic peaks of FAU-Y with a cell parameter of $2.43-2.44 \mathrm{~nm}$. For $\mathrm{NaOH} / \mathrm{Si}>0.05$, the intensity of FAU-Y peaks decreases with the increase of the $\mathrm{NaOH} / \mathrm{Si}$ ratio, meaning that the amount of zeolite in the material diminishes (Figure 1).

For $0.075<\mathrm{NaOH} / \mathrm{Si}<0.125$, a slight shift towards higher angle is observed for XRD peaks (111), (220), (311), (331), (533), (642) (Figure 1). Such a shift would correspond to unit cell parameters of $2.4085-2.4192 \mathrm{~nm}$ (Table 2), while for $\mathrm{NaOH} / \mathrm{Si}=0.15$ no shift of XRD peaks (111), (220) is observed. The shift towards higher angle can be due to a slight decrease of $\mathrm{Al}$ content in the zeolite framework ${ }^{28}$ during the transformation into FAUmes. However, such values of unit cell are below the lower limit of Al amount observed for dealuminated, desilicated or steamed FAU-Y, which corresponds to $\mathrm{a}_{0}=2.4265 \mathrm{~nm}$. This 
value corresponds to the extrapolated limit value attainable for a FAU-Y zeolite free of Al in its framework by using classical unit cell parameter as a function of $\mathrm{Al}$ atoms per unit cell relationships. $^{29}$

Some other phenomena can contribute to this shift such as the decrease in size of FAU-Y crystals and the formation of nanocrystals leading to a higher degree of contraction of the framework. ${ }^{30}$ The same effect has been observed for FAU-Y microcrystals grinded into nanocrystals with a shift of the (111) and (220) XRD peaks towards higher angles for 240 and $120 \mathrm{~nm}$ nanoparticles, while for $60 \mathrm{~nm}$ nanoparticles no shift for (111) and (220) XRD peaks was observed, but a shift towards lower angles for XRD peaks (533). ${ }^{30}$ We can therefore stipulate that the shift of FAU-Y XRD peaks in FAUmes is mainly due to the decrease in size of the FAU-Y domains when the $\mathrm{NaOH} / \mathrm{Si}$ ratio increases.

XRD peak intensities of FAU-Y drop to zero for $0.175<\mathrm{NaOH} / \mathrm{Si}<0.25$.

XRD performed at low angles (Figure 2) reveal no peak for $\mathrm{NaOH} / \mathrm{Si}=0.05$ demonstrating that this $\mathrm{NaOH} / \mathrm{Si}$ ratio is not sufficient to insure zeolite transformation into an ordered mesophase.

For $\mathrm{NaOH} / \mathrm{Si}=0.075$ and 0.10 a broad $\mathrm{XRD}$ peak at 2 theta $=1.7^{\circ}$ appears showing some organization of the mesoporous network, corresponding to a hexagonal cell parameter of $6.3 \mathrm{~nm}$.

For $0.125<\mathrm{NaOH} / \mathrm{Si}<0.175$, a very well-organized hexagonal structure of mesopores, as for MCM-41 materials, is observed with a first peak at 2 theta $=2.1^{\circ}$, corresponding to a hexagonal cell parameter of $4.9 \mathrm{~nm}$.

For higher amounts, $0.20<\mathrm{NaOH} / \mathrm{Si}<0.25$, a hexagonal mesoporous structure with a cell parameter of $5.0 \mathrm{~nm}$ is obtained with a larger diffraction peak in comparison to $0.125<$ $\mathrm{NaOH} / \mathrm{Si}<0.175$, suggesting smaller domain sizes of the ordered mesophase. The XRD modeling of the peak widths ${ }^{16}$ would estimate mesopore domain sizes inferior to $100 \mathrm{~nm}$ for $\mathrm{NaOH} / \mathrm{Si}=0.25$ and superior to $500 \mathrm{~nm}$ for $0.125<\mathrm{NaOH} / \mathrm{Si}<0.175$.

TEM pictures (Figure 3) show that the initial large pores $(>10 \mathrm{~nm}$ ) with a broad pore size distribution of the dealuminated zeolite FAU-Y have disappeared in FAUmes and are replaced by homogenously distributed mesopores (around $4 \mathrm{~nm}$ ) in the whole crystal.

TEM pictures (Figure 3, S1) reveal also the presence of crystalline FAU-Y domains of ca. $100 \mathrm{~nm}$ in size in FAUmes materials prepared with $0.075<\mathrm{NaOH} / \mathrm{Si}<0.125$. The size of the FAU-Y nanodomains decreases with the increase of $\mathrm{NaOH} / \mathrm{Si}$ ratio. These zeolite nanodomains are most probably responsible for the XRD peaks of FAU-Y in FAUmes (Figure 1). The size of FAU-Y nanodomains in FAUmes decreases upon increasing alkalinity, from ca. $100-200 \mathrm{~nm}$ for $\mathrm{NaOH} / \mathrm{Si}=0.0625-0.125$ to below $60 \mathrm{~nm}$ for higher $\mathrm{NaOH} / \mathrm{Si}$ ratio. The presence of FAU-Y nanodomains could be due to a heterogeneity of the aluminum distribution within the crystals of the initial dealuminated FAU-Y particles composed by an aggregation of crystals of different sizes and shapes. The larger crystals might be more difficult to dealuminate and should be less prone to transformation in basic medium into mesoporous Faujasite compared to smaller crystals. 
The well-organized hexagonal arrangement of mesopores revealed by XRD for 0.125 $<\mathrm{NaOH} / \mathrm{Si}<0.175$ is not clearly identified by TEM due probably to the large thickness of the samples.

By contrast, the ordered hexagonal structure is clearly observed for $0.20<\mathrm{NaOH} / \mathrm{Si}<$ 0.25 .

For $0.125<\mathrm{NaOH} / \mathrm{Si}<0.25$, one can see also the formation of additional extra-large pores $(>50 \mathrm{~nm})$, which increase in size and amount with the increase of $\mathrm{NaOH} / \mathrm{Si}$ ratio; it suggests a faster dissolution rate of FAU-Y compared to the rate of formation of the MCM41-like mesostructure for high $\mathrm{NaOH} / \mathrm{Si}$ ratio. The existence of these extra-large pores $(50-$ $200 \mathrm{~nm}$ ) for $0.20<\mathrm{NaOH} / \mathrm{Si}<0.25$ explains the increase of XRD diffraction peak width by the decrease of the mesopore domain size.

Textural properties of FAUmes determined from $\mathbf{N}_{\mathbf{2}}$ and Ar sorption isotherms. Nitrogen sorption isotherms at $77 \mathrm{~K}$ of FAUmes (Figure 4) show that the transformation of FAU-Y into FAUmes occurs with an increase of total pore volume when $\mathrm{NaOH} / \mathrm{Si}$ ratio increases, while total surface area remain constant $\left(\mathrm{S}_{\mathrm{BET}}=920 \pm 40 \mathrm{~m}^{2} / \mathrm{g}\right)($ Table 2$)$. The transformation of FAU-Y into FAUmes starts for $\mathrm{NaOH} / \mathrm{Si}=0.0625$ evidenced by the characteristic step of adsorption in the nitrogen isotherm at $\mathrm{p} / \mathrm{p}_{0} \sim 0.42$, as expected for MCM-41-like mesoporosity with similar mesopore diameters around $4 \mathrm{~nm}$ (Figure S2). Increasing the $\mathrm{NaOH} / \mathrm{Si}$ ratio leads to a shift of the adsorption step towards lower $\mathrm{p} / \mathrm{p}_{0}$ values, meaning that mesopore diameters are decreasing. Mesopore diameters are first constant at $4.37 \mathrm{~nm}$ for $0.0625<\mathrm{NaOH} / \mathrm{Si}<0.10$ and above $\mathrm{NaOH} / \mathrm{Si}=0.10$ mesopore diameters drop continuously from 4.4 to $3.9 \mathrm{~nm}$ with the increase of $\mathrm{NaOH} / \mathrm{Si}$, while MCM-41 materials feature a constant mesopore diameter of 3.9-4.0 nm (Tables 2, S1, Figure S3). If FAUmes is considered as a MCM-41 architecture built with FAU-Y walls, ${ }^{16}$ the wall thickness $e$ of the mesostructure can be calculated from the cell parameter $a$ of the mesostructure determined by XRD and the mesopore diameter $D$, as for MCM-41 materials, ${ }^{27}$ using the following equation:

$\mathrm{e}=\mathrm{a}-0.95 \mathrm{D}$

FAUmes synthesized with $0.0625<\mathrm{NaOH} / \mathrm{Si}<0.10$ feature mesopore diameters of $4.37 \mathrm{~nm}$ corresponding to wall thicknesses of $2.20 \mathrm{~nm}$ (Table 2) to $2.68 \mathrm{~nm}$ (Table S2). Such a value, close to that of the unit cell of FAU, would be compatible with the existence of crystalline walls of the mesophase as suggested in the case of a surfactant-assisted zeolite rearrangement process. The materials consist of FAU nanodomains co-existing with an ordered mesoporous zeolite.

For $\mathrm{NaOH} / \mathrm{Si}$ ratio above 0.10 , the wall thicknesses drop abruptly to ca. $1 \mathrm{~nm}$, which is too thin to accommodate a FAU-Y cell and is indicative of amorphous walls. This leads to a coexistence of FAU nanodomains with an ordered mesoporous phase as suggested in a dissolution-reassembly process.

Other features of FAUmes materials can be deducted from sorption isotherms (Figure 4). Large meso-/macropores $(20-300 \mathrm{~nm})$ due to the dealumination treatment of FAU-Y by steaming and/or acid leaching are present in the starting FAU-Y. Some of these large 
inhomogeneous pores are connected to the exterior of the crystal by the micropores of the zeolite, as revealed by a horizontal hysteresis between $0.43<\mathrm{p} / \mathrm{p}_{0}<1$.

For FAUmes materials prepared with $0.025<\mathrm{NaOH} / \mathrm{Si}<0.075$, this porosity is still observed. It disappears for $0.0875<\mathrm{NaOH} / \mathrm{Si}<0.125$.

Some new extra-large pores are formed for $0.125<\mathrm{NaOH} / \mathrm{Si}<0.25$, corresponding to the large holes or white spots observed in TEM images (Figures 3, S1).

Some of these extra-large pores are embedded into the crystal and connected to the exterior of the particles by the $4 \mathrm{~nm}$ mesopores, as revealed by the horizontal hysteresis between $0.43<\mathrm{p} / \mathrm{p}_{0}<1$ for $0.15<\mathrm{NaOH} / \mathrm{Si}<0.25$.

In literature ${ }^{21,31}$ it was shown that some of the $4 \mathrm{~nm}$ mesopores of FAUmes were also embedded into the crystals, which are not visible by $\mathrm{N}_{2}$ sorption at $77 \mathrm{~K}$, but can be revealed by Ar sorption at $77 \mathrm{~K}$. These embedded mesopores have been effectively observed for FAUmes materials synthesized with $0.0625<\mathrm{NaOH} / \mathrm{Si}<0.15$, as evidenced by the short horizontal hysteresis starting from the desorption step of surfactant-templated mesopores, corresponding to a constant volume of ca. $0.06 \mathrm{~mL} / \mathrm{g}$ (Figure $\mathrm{S} 4$ ).

We proposed that these mesopores are embedded in between zeolite nanodomains inside the crystal. For all $\mathrm{NaOH} / \mathrm{Si}$ ratios, Ar adsorption isotherms at $87 \mathrm{~K}$ show an adsorption step at low $\mathrm{p} / \mathrm{p}_{0}$ characteristic of FAU-Y supercages filling (Figure S4). The volume associated with this step corresponds to the micropore volume, and decreases with the increase of the $\mathrm{NaOH} / \mathrm{Si}$ ratio. This means that crystalline domains remain intact for all FAUmes materials $(0<\mathrm{NaOH} / \mathrm{Si}<0.25)$, even if the XRD peaks of FAU-Y are not distinguishable as for $0.175<\mathrm{NaOH} / \mathrm{Si}<0.25$ (Figure 1) due most probably to their small size.

The above results reveal that FAUmes materials present several features depending on the $\mathrm{NaOH} / \mathrm{Si}$ ratio:

1- For $0.0625<\mathrm{NaOH} / \mathrm{Si}<0.25$, surfactant-templated mesopores (ie mesopores with uniform size distributions) are formed and coexist with nanodomains of FAU-Y.

2- For $0<\mathrm{NaOH} / \mathrm{Si}<0.075$, presence of large pores with broad distributions of sizes due to the dealumination treatment are present.

3- For $0.0625<\mathrm{NaOH} / \mathrm{Si}<0.15$, embedded surfactant-templated mesopores are present.

4- For $0.0625<\mathrm{NaOH} / \mathrm{Si}<0.10$, wall thicknesses of surfactant-templated mesopores are large enough to possibly accommodate a FAU cell as suggested in the case of a surfactantassisted zeolite rearrangement process.

5- For $0.125<\mathrm{NaOH} / \mathrm{Si}<0.25$, wall thicknesses of surfactant-templated mesopores are too thin to accommodate a FAU cell, walls are most probably amorphous. There is a change of mechanism towards a dissolution-reassembly process. Extra-large pores $(50-200 \mathrm{~nm})$ are present.

Micropore and mesopore volumes (Table 3) of FAU-Y and FAUmes materials have been calculated from $\mathrm{Ar}$ adsorption isotherms at $87 \mathrm{~K}$ using cumulative pore volume determination (Figure S4) and by $\mathrm{N}_{2}$ adsorption isotherms at $77 \mathrm{~K}$ with corrected t-plot 
method $^{24}$ (Figure S5). Ar and $\mathrm{N}_{2}$ results follow the same trend with slightly larger pore volumes of $0.05 \mathrm{~mL} / \mathrm{g}$ for nitrogen measurements (Table 3).

The starting FAU-Y (CBV720) used in this study is a dealuminated FAU-Y; it presents a secondary network of micro-mesopores $(1.5-3 \mathrm{~nm})$ amounting to $0.05 \mathrm{~mL} / \mathrm{g}$ determined via $\mathrm{Ar}$ adsorption isotherm at $87 \mathrm{~K}$ (Figure S3). This secondary network contributes to an increase of the first slope in t-plot responsible for the slight overestimation of micropore volume $(0.371 \mathrm{~mL} / \mathrm{g})$ for CBV720 calculated by t-plot with $\mathrm{N}_{2}$ in comparison to $\operatorname{Ar}(0.300 \mathrm{~mL} / \mathrm{g})$ measurement obtained by cumulative pore volume. However if the volume of secondary network of micro-mesopores is added $(0.352 \mathrm{~mL} / \mathrm{g})$ the value is close to t-plot method. Ar at $87 \mathrm{~K}$ and cumulative pore volume determination should be preferred to $\mathrm{N}_{2} \mathrm{t}$ plot method for precise more micropore volume determination. However for comparison with literature results it is easier to use $\mathrm{N}_{2}$ measurements.

Micropore volume of FAU-Y should not exceed $0.36 \mathrm{~mL} / \mathrm{g}$ as FAU-Y present supercages volume of $0.283 \mathrm{~mL} / \mathrm{g}$ and sodalite cages volume of $0.08 \mathrm{~mL} / \mathrm{g}$, the later being usually not accessible to $\mathrm{N}_{2}$ and Ar, except when sodalite cages are opened by etching by chemical treatments as it could be probably the case for the present commercial zeolite. According to literature, the opening of sodalite cages is accompanied by the creation of $3 \mathrm{~nm}$ connected mesopores, as in the present case, presumably due to the merging of two supercages ${ }^{10}$ and leading to an increase of the acidity by creating accessible acid sites in opened sodalite cages. ${ }^{32}$ By treating FAU-Y with a low amount of $\mathrm{NaOH}(\mathrm{NaOH} / \mathrm{Si}=0.025)$ these small mesopores disappear by reticulating these defects in low basic medium, resulting in an initial slight decrease of mesopore volume (Figure 5). For FAUmes synthesized with $\mathrm{NaOH} / \mathrm{Si}>0.05$, mesopore and total volumes increase while micropore volumes decrease when the $\mathrm{NaOH} / \mathrm{Si}$ ratio increases (Figure 5). The increase of the mesopore volume of FAUmes is following the same trend as the one of MCM-41 synthesized with C18TAB and different $\mathrm{NaOH} / \mathrm{Si}$ ratio with a delay in $\mathrm{NaOH} / \mathrm{Si}$ ratio of 0.03 (Figure $\mathrm{S} 6$ ).

Textural properties of FAUmes determined by geometrical methods. In order to gain additional insight into the complex nature of FAUmes materials, and more particularly to look into the veracity of a MCM-41 like architecture (Figure S7) with walls made of FAU-Y as proposed recently in literature, ${ }^{16}$ micropore volumes have been calculated using a geometrical calculation based on the XRD cell parameter of the mesophase and the mesopore diameter as previously done for SBA-15 materials. ${ }^{25,26}$ Geometrical mesopore volumes $V_{\text {mes }}^{g}$ and micropore volumes $V_{\text {mic }}{ }^{g}$ (Table S3) have been determined using the mesopore diameter $D_{B d B}$, the cell parameter $a$ of the mesostructure, the total pore volume $V_{t o t}$ and FAU density $\rho_{F A U}\left(1.93 \mathrm{~g} / \mathrm{cm}^{3}\right)^{33}$ with the following equations:

$$
\begin{aligned}
& \varepsilon=\left[\mathrm{D}_{\mathrm{BdB}} /(1.05 \mathrm{a})\right]^{2} \\
& \mathrm{~V}_{\text {mes }}{ }^{\mathrm{g}}=\varepsilon /\left[(1-\varepsilon) \rho_{\mathrm{FAU}}\right] \\
& \mathrm{V}_{\text {mic }}{ }^{\mathrm{g}}=\mathrm{V}_{\text {tot }}-\mathrm{V}_{\text {mes }}{ }^{\mathrm{g}}
\end{aligned}
$$

For FAUmes synthesized with $0.075<\mathrm{NaOH} / \mathrm{Si}<0.25$, the geometrical values of mesopore volumes are extremely high, twice the volumes calculated by t-plot and Ar adsorption, leading to negative micropore volumes, which is unlikely. An explanation for this discrepancy 
could be a change of the density of the walls in FAUmes. However, such an assumption would result in a calculated density of $4.48 \mathrm{~g} / \mathrm{cm}^{3}$ (calculated for FAUmes synthesized with $\mathrm{NaOH} / \mathrm{Si}=0.125$ for example), which is not possible as the highest possible density should be $2.2 \mathrm{~g} / \mathrm{cm}^{3}$ as for amorphous silica or silico-aluminates. ${ }^{27}$ The model of MCM-41 architecture with FAU-Y walls alone is therefore unlikely to describe the FAUmes materials of the present study, though the existence of crystalline walls can be possible for materials prepared with $0.0625<\mathrm{NaOH} / \mathrm{Si}<0.10$ (with in addition zeolitic crystalline nanodomains well-dispersed in the crystal). For $\mathrm{NaOH} / \mathrm{Si}>0.10$, FAUmes have to be regarded as a mosaic of mesostructured amorphous domains and zeolitic crystalline nanodomains distributed over the whole crystal.

This assumption is fully in line with the TEM micrographs. The presence of FAU-Y nanodomains in the materials explains the presence of embedded surfactant-templated mesopores, which can be formed in between two FAU-Y nanodomains. The presence of these FAU-Y nanodomains explains also the observation of XRD peaks of FAU-Y for FAUmes synthesized with $0.125<\mathrm{NaOH} / \mathrm{Si}<0.15$, which walls cannot accommodate a FAU cell, and the micropore volumes filling occurring at the same $\mathrm{p} / \mathrm{p}_{0}$ in $\mathrm{Ar}$ isotherms for all $\mathrm{NaOH} / \mathrm{Si}$ ratios.

Acidity of FAUmes(C18) determined by $\mathbf{N H}_{3}$ TPD. It is of prime importance to verify if FAU-Y has kept its specific properties as its strong acidity during the transformation into FAUmes. FAUmes has been synthesized in $\mathrm{Na}^{+}$form due to the use of $\mathrm{NaOH}$ as basic medium. Cationic exchanges with $\mathrm{NH}_{4}{ }^{+}$followed by calcination have been performed to obtain $\mathrm{H}^{+}$-FAUmes. $\mathrm{H}^{+}$-FAU-Y has two kind of Brönsted acid sites: (1) Si-O(H)-Al groups in the supercages corresponding to a FTIR band at $3630 \mathrm{~cm}^{-1}$, and (2) $\mathrm{Si}-\mathrm{O}(\mathrm{H})-\mathrm{Al}$ groups in the sodalite cages corresponding to a FTIR band at $3570 \mathrm{~cm}^{-1}$. Modeling studies of the acidity of FAU-Y points to a bimodal energy distribution function for both types of silanol groups, where, about $64 \%$ of the $\mathrm{OH}$ groups are more acidic in the supercage, while in the sodalite units the figure is only about $38 \% .^{34}$

TPD of ammonia allows to readily dose the strong acidity of zeolites if a controlled methodology is followed. Indeed the measure may be affected by the experimental conditions, ${ }^{34,35}$ such as the ratio of sample weight to carrier gas flow rate, the rate of temperature increase and the particles size. $\mathrm{NH}_{3}$ desorption temperature can be governed by diffusion in large particles and therefore particle sizes smaller than $160 \mu \mathrm{m}$ are recommended. In this study, all experimental conditions are the same, FAU-Y and FAUmes feature similar particles size $(10-30 \mu \mathrm{m})^{22}$ and therefore comparison of $\mathrm{NH}_{3}$ TPD analysis can be done safely. The peak of desorption at low temperature (at around $200^{\circ} \mathrm{C}$ ) is not taken into account as possible $\mathrm{NH}_{3}$ desorption-readsorption or clustering phenomena can take place. ${ }^{36}$ Only the peak at high temperature $\left(300-500{ }^{\circ} \mathrm{C}\right)$ usually associated with the strong Brönsted acidity in most zeolites ${ }^{34,37}$ has been considered and used to characterize the strong acidity of zeolites. Moreover relative amounts of strong acidity of the materials have been used and compared rather than absolute values. Under appropriate conditions, good agreement between Brönsted acidity determined by FTIR of adsorbed Pyridine, n-hexane cracking and the area of the high temperature peak of $\mathrm{NH}_{3}$ TPD has been observed for zeolites (BEA), with a slightly lower amount of strong acidity found by $\mathrm{NH}_{3}$ TPD. ${ }^{38}$ Acidity characterization of FAUmes materials using cetyltrimethylammonium as surfactant and $\mathrm{NH}_{4} \mathrm{OH}$ as basic medium (FAUmes(C16)) 
has been reported recently ${ }^{4}$ and revealed a good agreement between the relative amount of strong acidity determined by $\mathrm{NH}_{3}$ TPD (peak centered at $380-390{ }^{\circ} \mathrm{C}$ ), the relative amount of strong Brönsted acidity determined by $\mathrm{CO}$ adsorption followed by FTIR and by the area of the FTIR Si-O(H)-Al supercage signal at $3630 \mathrm{~cm}^{-1}$.

In the present study, $\mathrm{NH}_{3}$ TPD profiles have been fitted with two Gaussian peaks and only the peak at high temperature has been considered. The maximum of the high temperature $\mathrm{NH}_{3}$ TPD peak for initial $\mathrm{H}^{+}-\mathrm{FAU}-\mathrm{Y}$ is at $380{ }^{\circ} \mathrm{C}$ and corresponds to $0.46 \pm 0.03 \mathrm{mmol} / \mathrm{g}$ of strong acidity (Figure S8). The intensity of the strong acidity peak decreases globally with the decrease of micropore volume (Figure 6), so with the decrease of zeolite content. The decrease of the number of strong acid sites on zeolites USY modified in the presence of a template has also been reported by Rac et al. ${ }^{39}$ The first drop of acidity between initial FAU$\mathrm{Y}$ and FAUmes from $0.46 \pm 0.03 \mathrm{mmol} / \mathrm{g}$ to $0.30 \pm 0.03 \mathrm{mmol} / \mathrm{g}$ could be ascribed to the loss of accessible acid sites in initial opened sodalite cages ${ }^{32}$ by reticulation of the defects under basic medium leading to only supercages acidity, which corresponds to $64 \%$ of the overall strong acidity. A second drop in acidity is observed for FAUmes synthesized with $\mathrm{NaOH} / \mathrm{Si}$ above 0.10 , when amorphous walls replace presumable crystalline walls.

Interestingly, the relative amount of strong Brönsted acidity of the FAUmes(C16) materials ${ }^{4}$ mentioned above determined by $\mathrm{CO}$ adsorption followed by FTIR and by the area of the FTIR Si-O(H)-Al supercage bands at $3630 \mathrm{~cm}^{-11}$ have been reported in Figure 6 as a function of their micropore volume determined by our t-plot method. Both sets of data fit perfectly a unique correlation and indicate conclusively that the origin of the strong acidity of FAUmes materials is essentially $(>80 \%)$ zeolite Brönsted acidity.

\section{CONCLUSIONS}

Mesoporous FAU-Y materials synthesized by transformation of FAU-Y ( $\mathrm{Si} / \mathrm{Al}=15)$ in basic $\mathrm{NaOH}$ medium in the presence of octadecyltrimethylammonium surfactant at $115^{\circ} \mathrm{C}$ for $20 \mathrm{~h}$ (FAUmes) constitute a complex family of materials featuring different textural and acidic properties depending on the $\mathrm{NaOH} / \mathrm{Si}$ ratio used in the reacting mixture (Figure 7). The transformation of FAU-Y into FAUmes with homogeneous mesopores of ca. $4 \mathrm{~nm}$ diameter begins for $\mathrm{NaOH} / \mathrm{Si}=0.0625$. Upon increasing the $\mathrm{NaOH} / \mathrm{Si}$ ratio, the mesopore volume increases and the micropore volume decreases. The transformation occurs at constant total surface area. All materials contain intact FAU-Y crystalline nanodomains, which size decreases by increasing $\mathrm{NaOH} / \mathrm{Si}$ ratio. The strong acidity of the materials decreases with the decrease of micropore volume, that is, with the decrease of the crystalline zeolite fraction.

Mesoporous FAU-Y materials family feature at least 3 types of hierarchical structures: FAUmes with presumably crystalline walls containing well-dispersed zeolite nanodomains and an interconnected mesopore network $(0.0625<\mathrm{NaOH}<0.10)$, Al-MCM-41 like materials with well-dispersed zeolite nanodomains $(0.125<\mathrm{NaOH}<0.175)$, Al-MCM-41 materials with an interconnected macroporous network. Two materials would be very promising for applications needing high diffusivity: FAUmes prepared with $\mathrm{NaOH} / \mathrm{Si}=0.10$ featuring large mesopore volume and high acidity, and Al-MCM-41 prepared with $\mathrm{NaOH} / \mathrm{Si}$ $=0.25$ featuring large macropore volume and mild acidity. 


\section{ACKNOWLEDGMENTS}

The authors thank TOTAL S. A. for financial support and I. Ivanova for providing nitrogen isotherms data for the t-plot calculations of FAUmes(C16).

Supporting Information: Additional TEM of FAUmes, $\mathrm{N}_{2}$ sorption isotherms of MCM-41 materials and characterization, Ar isotherms of FAUmes at 87 and $77 \mathrm{~K}$, t-plot corrections formula, $\mathrm{NH}_{3}$ TPD spectra. 


\section{REFERENCES}

(1) Vermeiren, W.; Gilson, J-P. Impact of zeolites on the petroleum and petrochemical industry, Top. Cata., 2009, 52, 1131-1161.

(2) van Donk, S.; Janssen, A.H.; Bitter, J.H.; de Jong, K.P., Generation, Characterization, and Impact of Mesopores in Zeolite Catalysts, Catal. Rev. Sci. Eng., 2003, 45, 297-31.

(3) Corma, A. From Microporous to Mesoporous Molecular Sieve Materials and Their Use in Catalysis Chem. Rev., 1997, 97 (6), 2373-2420.

(4) Kazakov, M. O.; Nadeina, K. A.; Danilova, I. G.; Dik, P. P.; Klimov, O. V.; Pereyna, V. Yu.; Gerasimov, E. Yu.; Dobryakova, I. V.; Knyazeva, E. E.; Ivanova, I. I.; Noskov, A. S. Hydrocracking of Vacuum Gas Oil over $\mathrm{NiMo} / \gamma-\mathrm{Al}_{2} \mathrm{O}_{3}$ : Effect of Mesoporosity Introduced by Zeolite Y Recrystallization, Catal. Today, 2018, 305, 117-125.

(5) Bellussi, G. ; Millini, R. ; Pollesel, P.; Perego, C. Zeolite science and technology at Eni, New J. Chem., 2016, 40 (5), 4061-4077.

(6) Serrano, D. P.; Escola, J. M.; Sanz, R.; Garcia, R. A.; Peral, A.; Moreno, I.; Linares, M. Hierarchical ZSM-5 zeolite with uniform mesopores and improved catalytic properties, New J. Chem., 2016, 40 (5), 4206-4216.

(7) Ivanova, I. I.; Knyazeva, E. E. Micro-mesoporous materials obtained by zeolite recrystallization: synthesis, characterization and catalytic applications, Chem. Soc. Rev., 2013, 42 (9), 3671-3688.

(8) Perez-Ramirez, J.; Mitchell, S.; Verboekend, D.; Milina, M.; Michels, N-L.; Krumeich, F.; Marti, N.; Erdmann, M. Expanding the Horizons of Hierarchical Zeolites: Beyond Laboratory Curiosity towards Industrial Realization, ChemCatChem, 2011, 3, 1731-1734.

(9) Mitchell, S.; Michels, N-L.; Kunze, K.; Perez-Ramirez, J. Visualization of hierarchically structured zeolite bodies from macro to nano length scales, Nat. Chem., 2012, 4 (10), 825 831.

(10) De Jong, K. P.; Zecevic, J.; Friedrich, H.; de Jongh, P. E.; Bulut, M.; van Donk, S.; Kenmogne, R.; Finiels, A.; Hulea, V.; Fajula, F. Zeolite Y with trimodal porosity as ideal hydrocracking catalysts, Angew. Chem., 2010, 49-52, 10074-10078.

(11) Kortunov, P.; Vasenkov, S.; Karger, J.; Valiullin, R.; Gottschalk, P.; Fe Elia, M.; Perez, M.; Stocker, M.; Drescher, B.; McElhiney, G.; Berger, C.; Glaser, R.; Weitkamp, J. The role of mesopores in intracrystalline transport in USY zeolite: PFG NMR diffusion study on various length scales, J. Amer. Chem. Soc., 2005, 127, 13055-13059. 
(12) Galarneau, A.; Abid, Z.; Said, B.; Didi, Y.; Szymanska, K.; Jarzebski, A.; Tancret, F. ; Hamaizi, H.; Bengueddach, A.; Di Renzo, F.; Fajula, F. Synthesis and Textural Characterization of Mesoporous and Meso-/Macroporous Silica Monoliths Obtained by Spinodal Decomposition, Inorganics, 2016, 4(2), 9.

(13) Adem, Z.; Guenneau, F.; Springuel-Huet, M-A.; Gedeon, A. ; Iapichella, J.; Cacciaguerra, T. ; Galarneau, A. Diffusion Properties of Hexane in Pseudomorphic MCM-41 Mesoporous Silicas Explored by Pulsed Field Gradient NMR, J. Phys. Chem. C, 2012, 116, 13749-13759.

(14) Ying, J.; Garcia-Martinez, J. Mesostructured zeolitic materials, and methods of making and using the same US patent 2005, US20050239634.

(15) Li, K.; Valla, J.; Garcia-Martinez, J. Realizing the Commercial Potential of Hierarchical Zeolites: New Opportunities in Catalytic Cracking, Chem. Cat. Chem., 2014, 6, 46-66.

(16) Linares, N.; Sachse, A.; Serrano, E.; Grau-Atienza, A.; De Oliveira Jardim, E.; SilvestreAlbero, J.; Cordeiro, M. A. L.; Fauth, F.; Beobide, G.; Castillo, O.; García-Martínez, J. In Situ Time-Resolved Observation of the Development of Intracrystalline Mesoporosity in USY Zeolite, Chem. Mater., 2016, 28 (24), 8971-8979.

(17) Sachse, A.; Grau-Atienza, A.; Jardim, E. O.; Linares, N.; Thommes, M.; Garcia-Martinez J., Development of intracrystalline mesoporosity in zeolites through surfactant-templating, Cryst. Growth Des., 2017, 17, 4289-4305.

(18) Sachse, A.; Garcia-Martinez, J., Surfactant-templating of zeolites: from design to application, Chem. Mater., 2017, 29, 3827-3853.

(19) Verboekend, D.; Milina, M.; Mitchell, S.; PereRamirez, J., Hierarchical zeolites by desilication: occurrence and catalytic impact of recrystallization and restructuring, Cryst. Growth Des., 2013, 13 (11), 5025-5035.

(20) Verboekend, D.; Nuttens, N.; Locus, R., Van Aelst, J.; Verolme, P.; Groen, J. C.; PerezRamirez, J.; Sels, B. F. Synthesis, characterization and catalytic evaluation of hierarchical faujasite zeolites: milestone, challenges, and future directions, Chem. Soc. Rev., 2016, 45, 3331-3352.

(21) Garcia-Martinez, J.; Xiao, C.; Cychosz, K. A.; Li, K.; Wan, W.; Zou, X.; Thommes, M. Evidence of Intracrystalline Mesostructured Porosity in Zeolites by Advanced Gas Sorption, Electron Tomography and Rotation Electron Diffraction, Chem. Cat. Chem., 2014, 6 (11), 3110-3115. 
(22) Galarneau, A.; Guenneau, F.; Gedeon, A.; Mereib, D.; Rodriguez, J.; Fajula, F.; Coasne, B. Probing Interconnectivity in Hierarchical Microporous/Mesoporous Materials Using Adsorption and Nuclear Magnetic Resonance Diffusion, J. Phys. Chem. C, 2016, 120, 15621569 .

(23) Chal, R.; Cacciaguera, T., Van Donk, S.; Gerardin, C. Pseudomorphic synthesis of mesoporous zeolite Y crystals, Chem. Comm., 2010, 46, 7840-7842.

(24) Galarneau, A.; Villemot, F.; Rodriguez, J.; Fajula, F.; Coasne, B. Validity of the t-plot Method to Assess Microporosity in Hierarchical Micro/Mesoporous Materials, Langmuir, 2014, 30 (44), 13266-13274.

(25) Galarneau, A.; Cambon, H.; Di Renzo, F.; Fajula, F. True Microporosity and Surface Area of Mesoporous SBA-15 Silicas as a Function of Synthesis Temperature, Langmuir, 2001, 17 (26), 8328-8335.

(26) Galarneau, A.; Cambon, H.; Di Renzo, F.; Ryoo, R. ; Choi, M. Fajula, F., Microporosity and connections between pores in SBA-15 mesostructured silicas as a function of the temperature of synthesis, New J. Chem., 2003, 27 (1), 73-79.

(27) Galarneau, A.; Desplantier, D.; Dutartre, R.; Di Renzo, F. Micelle-templated silicates as a test bed for methods of mesopore size evaluation, Microporous Mesoporous Mater., 1999, 27 (2-3), 297-308.

(28) Al-Zaidi, B. Y.; Holmes, R. J.; Garforth, A. A. Study of the relationship between framework cation levels of $\mathrm{Y}$ zeolites and behavior during calcination, steaming, and $\mathrm{n}$ heptane cracking processes, Ind. Eng. Chem. Res., 2012, 51, 6648-6657.

(29) Sohn, J. R., DeCanio S. J., Lunsford, J. H., O'Donnell, D. J. Determination of framework aluminium content in dealuminated Y-type zeolites: a comparison based on unit cell size and wavenumber of i.r. bands, Zeolites, 1986, 6 (3), 225-227.

(30) Kong, C.; Tsuru, T. Zeolite nanocrystals prepared from zeolite microparticles by a centrifugation-assisted grinding method, Chem. Eng. Process., 2010, 49, 809-814.

(31) Cychosz, K. A.; Guillet-Nicolas, R.; Garcıa-Martınez, J. ; Thommes, M. Recent advances in the textural characterization of hierarchically structured nanoporous materials, Chem. Soc. Rev., 2017, 46 (2), 389-414.

(32) Qin, Z.; Cychosz, K. A., Melinte, G.; El Siblani, H.; Gilson, J-P.; Thommes, M.; Fernandez, C.; Mintova, S.; Ersen, O.; Valtchev, V. Opening the cages of Faujasite-type zeolite, J. Amer. Chem. Soc., 2017, 139, 17273-17276. 
(33) Pluth, J. J.; Smith, J. V. Positions of cations and molecules in zeolites with the faujasitetype, framework VII. Dehydrated Ca-exchanged X, Mater. Research Bull., 1972, 7, 13111322.

(34) Hunger, B.; Heuchel, M.; Clark, L. A.; Snurr, R. Q. Characterization of Acidic OH Groups in Zeolites of Different Types: An Interpretation of NH3-TPD Results in the Light of Confinement Effects, J. Phys. Chem. B, 2002, 106 (15), 3882-3889.

(35) Niwa, M.; Katada, N. New Method for the Temperature- Programmed Desorption (TPD) of Ammonia Experiment for Characterization of Zeolite Acidity: A Review, Chem. Rec., 2013, 13 (5), 432-455.

(36) Zecchina, A., Marchese, L.; Bordiga, S.; Paze, C.; Gianotti, E. Vibrational Spectroscopy of $\mathrm{NH}_{4}{ }^{+}$Ions in Zeolitic Materials: An IR Study, J. Phys. Chem. B, 1997, 101 (48), 10128 10135 .

(37) Padro, C. L.; Apesteguia, C. R. Acylation of phenol on solid acids: Study of the deactivation mechanism, Catal. Today, 2005, 107-108, 258-265.

(38) Benghalem, M. A. PhD thesis, 2017, University of Poitiers, France (in french).

(39) Rac, V.; Rakic, V.; Stošic, D.; Otman, O.; Auroux, A. Hierarchical ZSM-5, Beta and USY zeolites: Acidity assessment by gas and aqueous phase calorimetry and catalytic activity in fructose dehydration reaction, Microporous Mesoporous Mater., 2014, 194, 126-134. 
Table 1. Amount of $\mathrm{NaOH}$ used in the synthesis of FAUmes.

\begin{tabular}{ll}
\hline$n \mathrm{NaOH}(\mathrm{mol})$ & $x \mathrm{NaOH}(\mathrm{g})$ \\
\hline 0.025 & 0.199 \\
0.05 & 0.399 \\
0.075 & 0.599 \\
0.1 & 0.799 \\
0.125 & 0.999 \\
0.15 & 1.198 \\
0.175 & 1.398 \\
0.20 & 1.598 \\
0.25 & 1.998 \\
\hline
\end{tabular}

Table 2. XRD and $\mathrm{N}_{2}$ sorption isotherms results of FAUmes as a function of $\mathrm{NaOH} / \mathrm{Si}$ ratio used in the synthesis: $a_{0}$ cell parameter of FAU-Y-like microporosity, $a$ cell parameter of the MCM-41-like mesoporosity, $\mathrm{D}_{\mathrm{BdB}}$ mesopore diameter, $e$ wall thickness, specific surface area $S_{B E T}$, total pore volume $V_{t o t}$.

\begin{tabular}{lllllll}
\hline $\mathrm{NaOH} / \mathrm{Si}$ & $\mathrm{a}_{0}(\mathrm{~nm})$ & $\mathrm{a}(\mathrm{nm})$ & $\mathrm{D}_{\mathrm{BdB}}(\mathrm{nm})$ & $\mathrm{e}(\mathrm{nm})$ & $\mathrm{S}_{\mathrm{BET}}\left(\mathrm{m}^{2} / \mathrm{g}\right)$ & $\mathrm{V}_{\text {tot }}(\mathrm{mL} / \mathrm{g})$ \\
\hline 0 & 2.428 & none & - & - & 937 & 0.431 \\
0.025 & 2.434 & none & - & - & 868 & 0.478 \\
0.05 & 2.437 & none & 4.30 & - & 861 & 0.437 \\
0.075 & 2.408 & 6.35 & 4.37 & 2.20 & 894 & 0.534 \\
0.10 & 2.416 & 6.35 & 4.37 & 2.20 & 926 & 0.634 \\
0.125 & 2.419 & 4.94 & 4.34 & 0.82 & 957 & 0.714 \\
0.15 & 2.434 & 4.94 & 4.24 & 0.91 & 949 & 0.766 \\
0.175 & none & 4.70 & 4.14 & 0.77 & 960 & 0.782 \\
0.25 & none & 5.09 & 3.91 & 1.38 & 954 & 0.811
\end{tabular}


Table 3. Micropore and mesopore volumes of FAUmes synthesized with different $\mathrm{NaOH} / \mathrm{Si}$ ratio obtained by nitrogen adsorption isotherms at $77 \mathrm{~K}$ and $\mathrm{Ar}$ adsorption isotherms at $87 \mathrm{~K}$.

\begin{tabular}{llllllll}
\hline $\mathrm{NaOH} / \mathrm{Si}$ & $\begin{array}{l}\mathrm{V}_{\text {tot }} \\
(\mathrm{Ar})\end{array}$ & $\begin{array}{l}\mathrm{V}_{\text {mic }} \\
(\mathrm{Ar})\end{array}$ & $\begin{array}{l}\mathrm{V}_{\text {mes }} \\
(\mathrm{Ar})\end{array}$ & $\begin{array}{l}\mathrm{V}_{\text {tot-tpt }} \\
\left(\mathrm{N}_{2}\right)\end{array}$ & $\begin{array}{l}\mathrm{V}_{\text {mic-tpt }} \\
\left(\mathrm{N}_{2}\right)\end{array}$ & $\begin{array}{l}\mathrm{V}_{\text {mic-cor }} \\
\left(\mathrm{N}_{2}\right)\end{array}$ & $\begin{array}{l}\mathrm{V}_{\text {mes-cor }} \\
\left(\mathrm{N}_{2}\right)\end{array}$ \\
& $\mathrm{mL} / \mathrm{g}$ & $\mathrm{mL} / \mathrm{g}$ & $\mathrm{mL} / \mathrm{g}$ & $\mathrm{mL} / \mathrm{g}$ & $\mathrm{mL} / \mathrm{g}$ & $\mathrm{mL} / \mathrm{g}$ & $\mathrm{mL} / \mathrm{g}$ \\
\hline 0 & 0.378 & 0.300 & 0.078 & 0.431 & 0.265 & 0.371 & 0.060 \\
0.025 & & & & 0.383 & 0.258 & 0.361 & 0.022 \\
0.05 & & & & 0.437 & 0.233 & 0.326 & 0.111 \\
0.0625 & & & & 0.479 & 0.222 & 0.311 & 0.168 \\
0.075 & 0.497 & 0.249 & 0.248 & 0.534 & 0.209 & 0.280 & 0.254 \\
0.0875 & & & & 0.592 & 0.190 & 0.242 & 0.350 \\
0.10 & 0.581 & 0.208 & 0.373 & 0.634 & 0.180 & 0.222 & 0.411 \\
0.125 & 0.657 & 0.170 & 0.487 & 0.714 & 0.149 & 0.170 & 0.544 \\
0.15 & 0.718 & 0.130 & 0.588 & 0.766 & 0.116 & 0.122 & 0.644 \\
0.175 & & & & 0.782 & 0.102 & 0.103 & 0.678 \\
0.20 & & & & 0.790 & 0.085 & 0.085 & 0.705 \\
0.25 & 0.748 & 0.055 & 0.693 & 0.811 & 0.057 & 0.057 & 0.754 \\
\hline
\end{tabular}




\section{Figure captions}

Figure 1. XRD pattern (high angles) of FAUmes prepared with different $\mathrm{NaOH} / \mathrm{Si}$ ratio. Inset. Magnification of (220) XRD peak of FAU-Y.

Figure 2. XRD pattern (low angles) of FAUmes prepared with different $\mathrm{NaOH} / \mathrm{Si}$ ratio.

Figure 3. TEM of FAUmes prepared with different $\mathrm{NaOH} / \mathrm{Si}$ ratio. Rectangle evidences FAU-Y nanodomains.

Figure 4. Nitrogen sorption isotherms at $77 \mathrm{~K}$ of FAUmes prepared with different $\mathrm{NaOH} / \mathrm{Si}$ ratio.

Figure 5. Total pore volumes, mesopore volumes and micropore volumes of FAUmes prepared with different $\mathrm{NaOH} / \mathrm{Si}$ ratio determined by $\mathrm{N}_{2}$ adsorption at $77 \mathrm{~K}$ with corrected tplot method.

Figure 6. Relative amount of strong acidity determined by $\mathrm{NH}_{3}$ TPD (circle) as a function of micropore volume and comparison with literature ${ }^{4}$ results (square): relative strong Brönsted acidity of FAUmes determined by CO-FTIR (red) and by FTIR band intensity of $\mathrm{SiO}(\mathrm{H}) \mathrm{Al}$ in supercages (blue). Initial strong acidity of FAU-Y CBV720: $0.46 \mathrm{mmol} / \mathrm{g}$.

Figure 7. Schematic representation of FAUmes materials as a function of $\mathrm{NaOH} / \mathrm{Si}$ ratio used in the synthesis. 
Figure 1

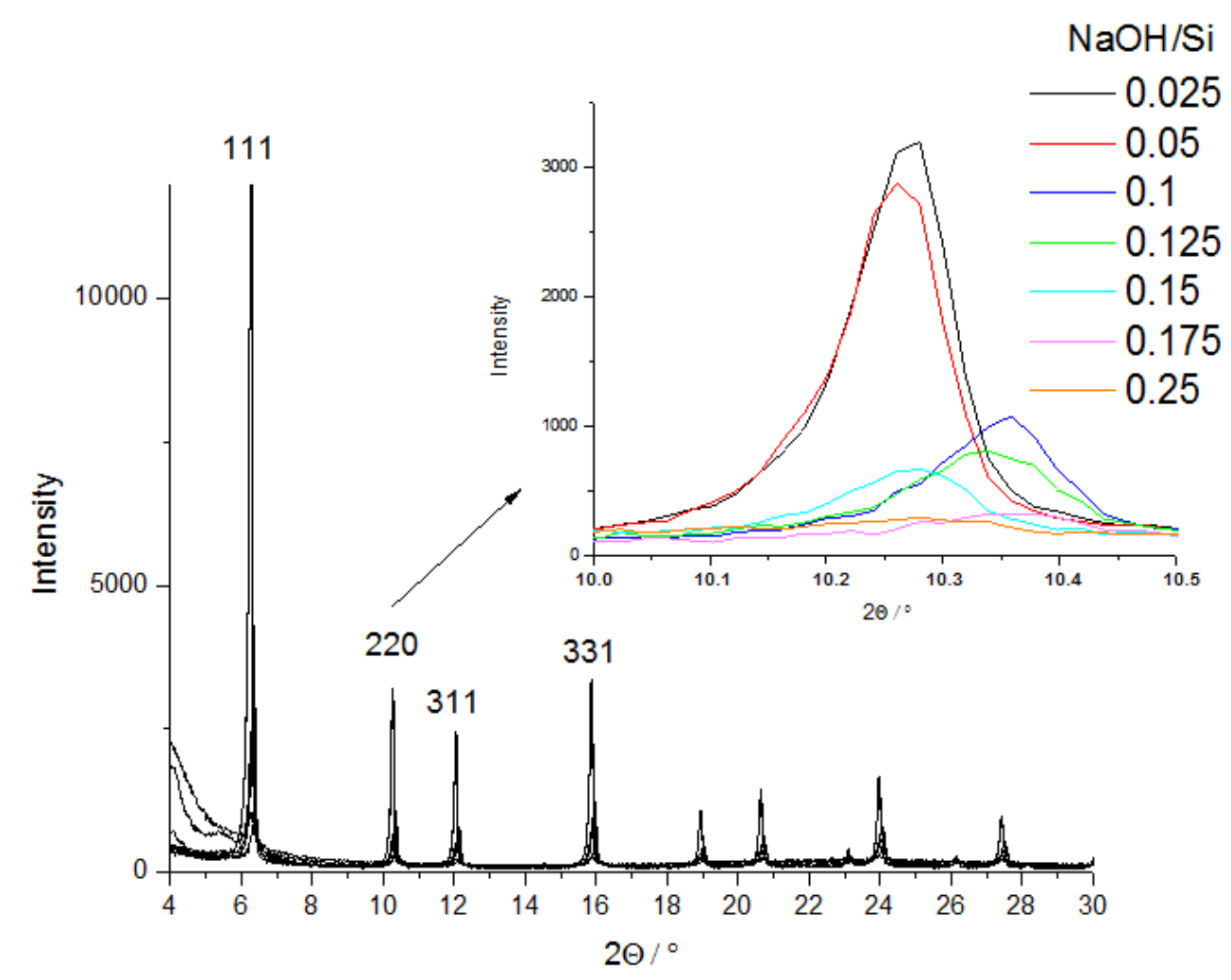




$$
\begin{aligned}
& 1 \\
& 2 \\
& 4 \\
& 5 \\
& 6 \\
& 7 \\
& 8 \\
& 9 \\
& 10 \\
& 11 \\
& 12 \\
& 13 \\
& 14 \\
& 15 \\
& 16 \\
& 17 \\
& 18 \\
& 19 \\
& 20 \\
& 21 \\
& 22 \\
& 23 \\
& 24 \\
& 25 \\
& 26 \\
& 27 \\
& 28 \\
& 29 \\
& 30 \\
& 31 \\
& 32 \\
& 33 \\
& 34
\end{aligned}
$$

Figure 2

Required parameters are missing or incorrect.
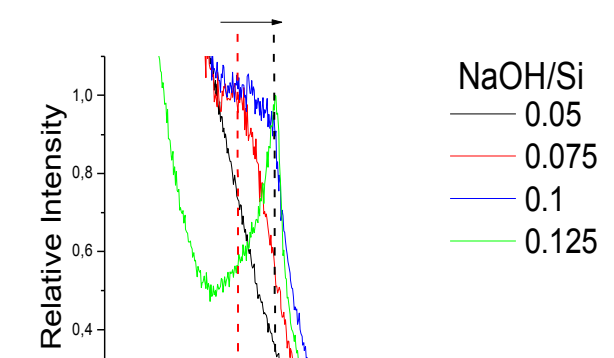

$\stackrel{\bar{\alpha}}{\square} 0$
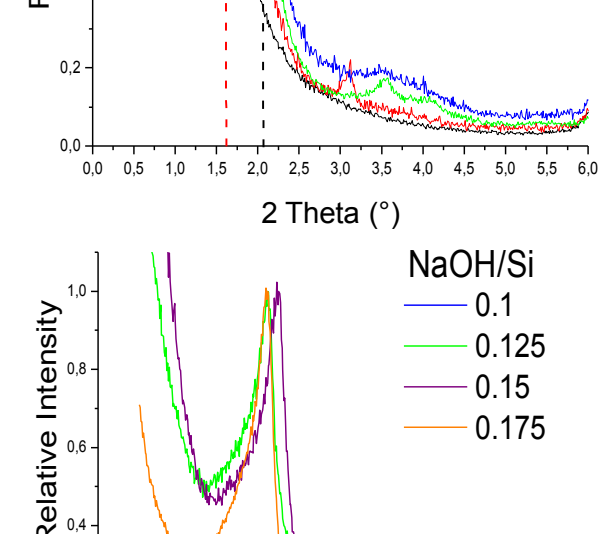

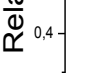

$0,2-$

0,0

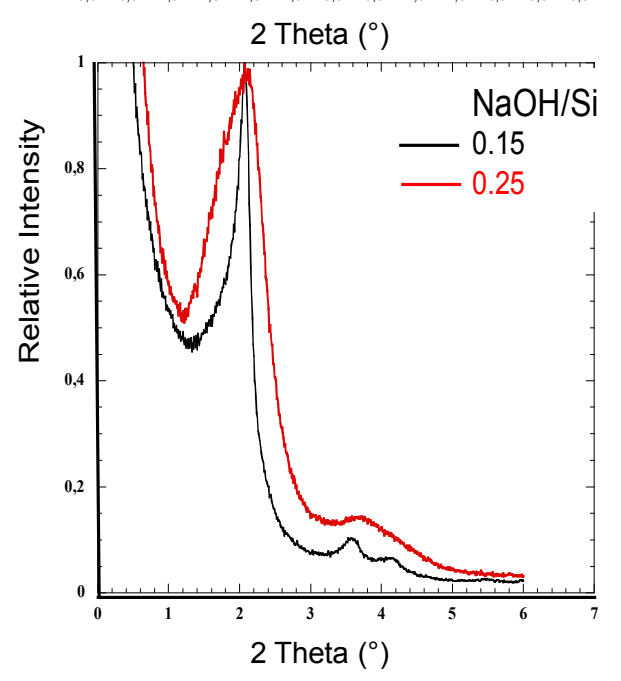


Figure 3

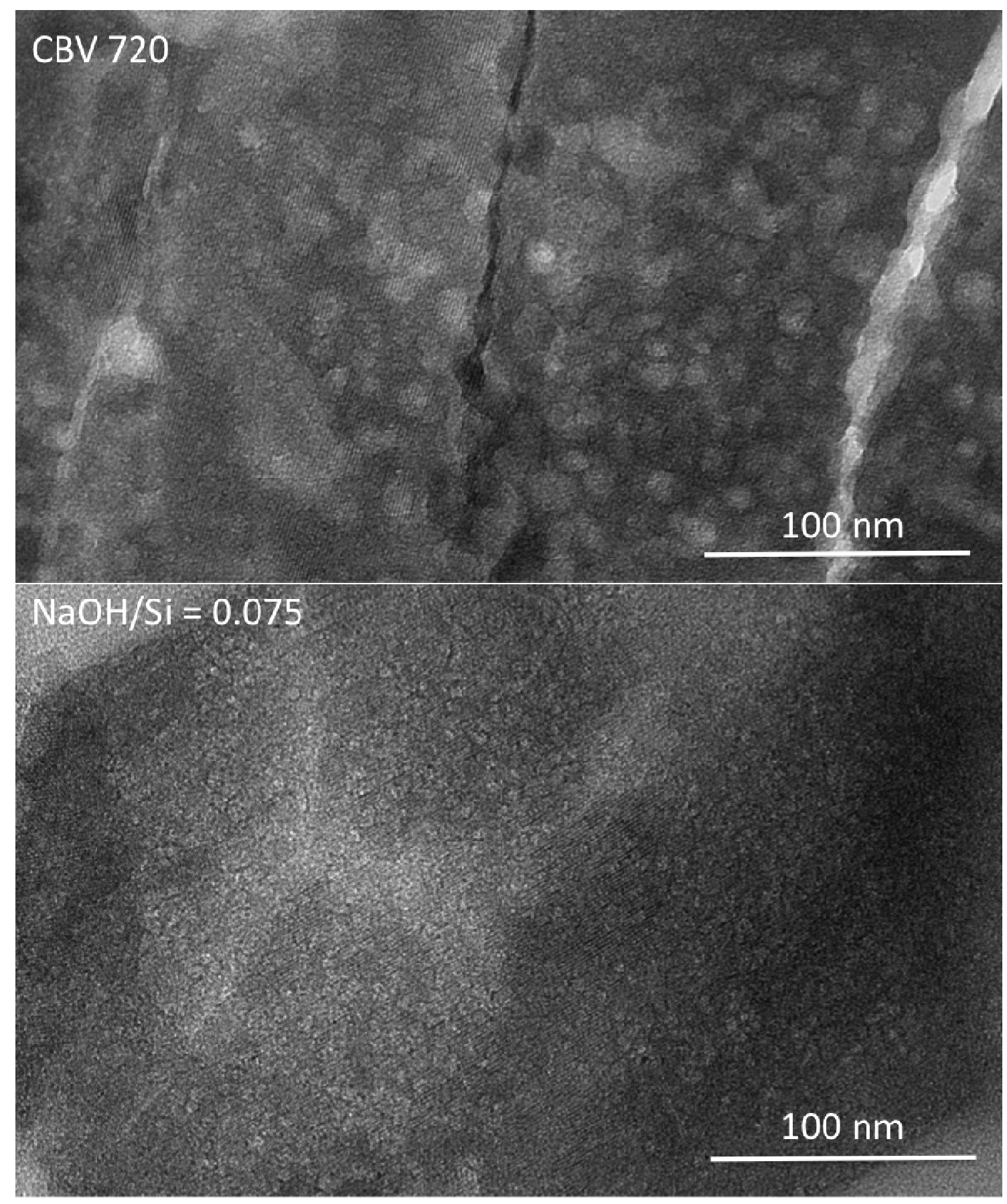




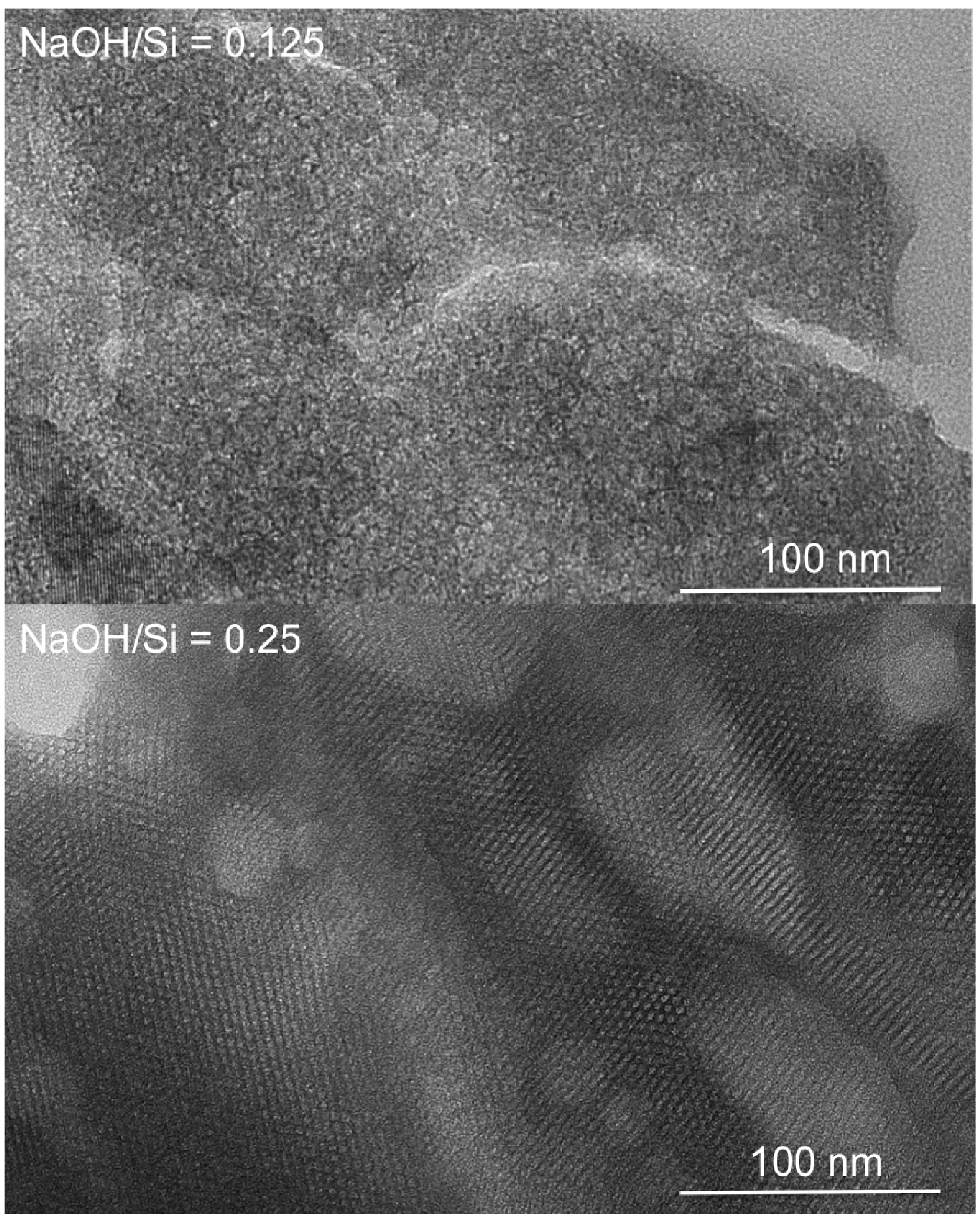




$$
\begin{aligned}
& 1 \\
& 2 \\
& 3 \quad \mathrm{NaOH} / \mathrm{Si}=0.075 \\
& \begin{array}{l}
4 \\
5
\end{array} \\
& 6 \\
& 7 \\
& 8 \\
& 9 \\
& 11 \\
& 12 \\
& 13 \\
& 14 \\
& 15 \\
& 16 \\
& 18 \\
& 19 \\
& 20 \\
& 21 \\
& 22 \\
& 23 \\
& 24 \\
& 25 \\
& 26 \\
& 27 \\
& 28 \\
& 29 \\
& 30 \\
& 31 \\
& 32 \\
& 33 \\
& 34 \\
& 35 \\
& 36 \\
& 37 \\
& 38 \\
& 39 \\
& 40 \\
& 41 \\
& 42 \\
& 43 \\
& 44 \\
& 45 \\
& 46 \\
& 47 \\
& 48 \\
& 49 \\
& 50 \\
& 51 \\
& 52 \\
& 53 \\
& 54 \\
& 55 \\
& 56 \\
& 58 \\
& 59 \\
& 60
\end{aligned}
$$

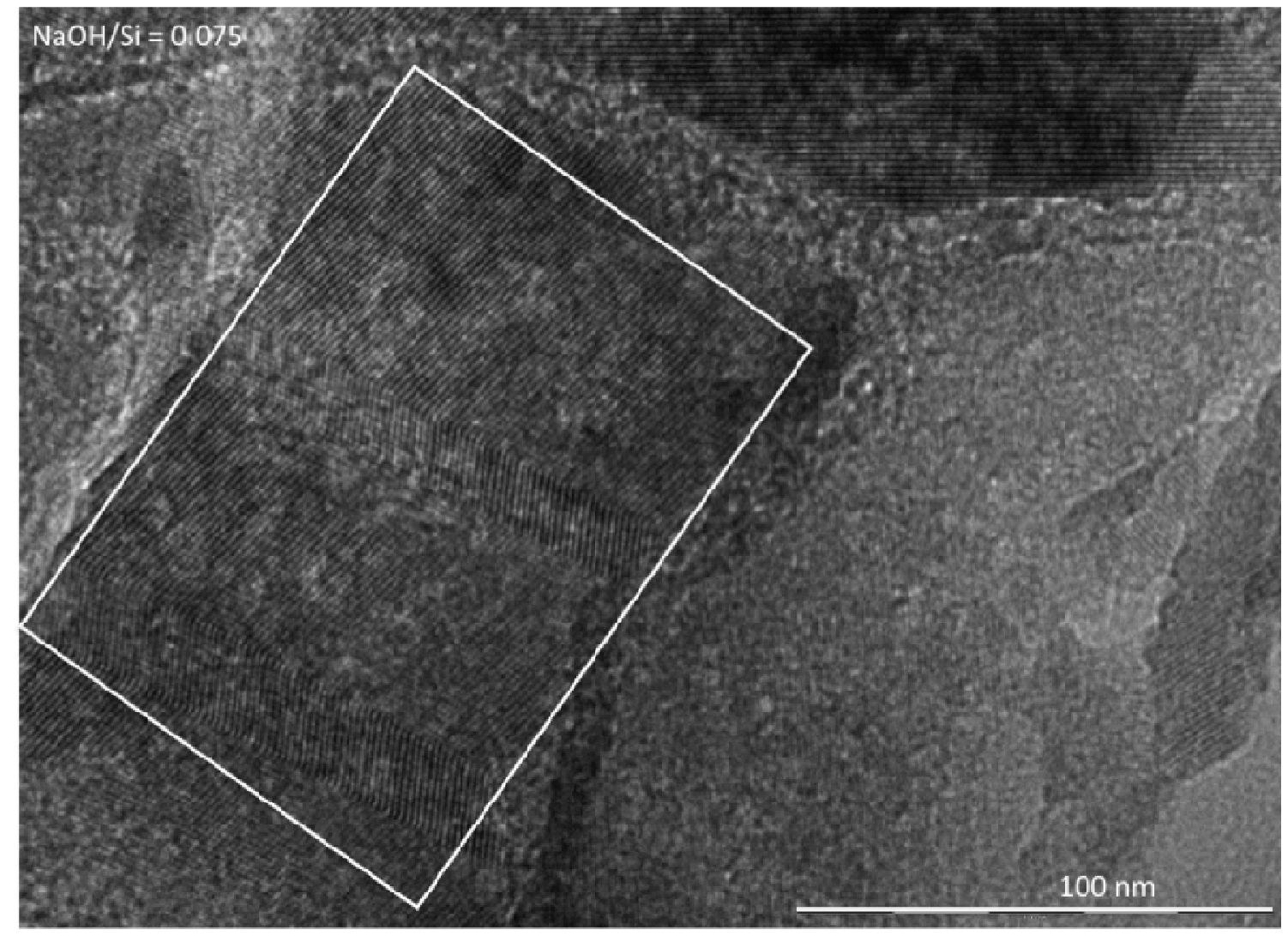




\section{Figure 4}

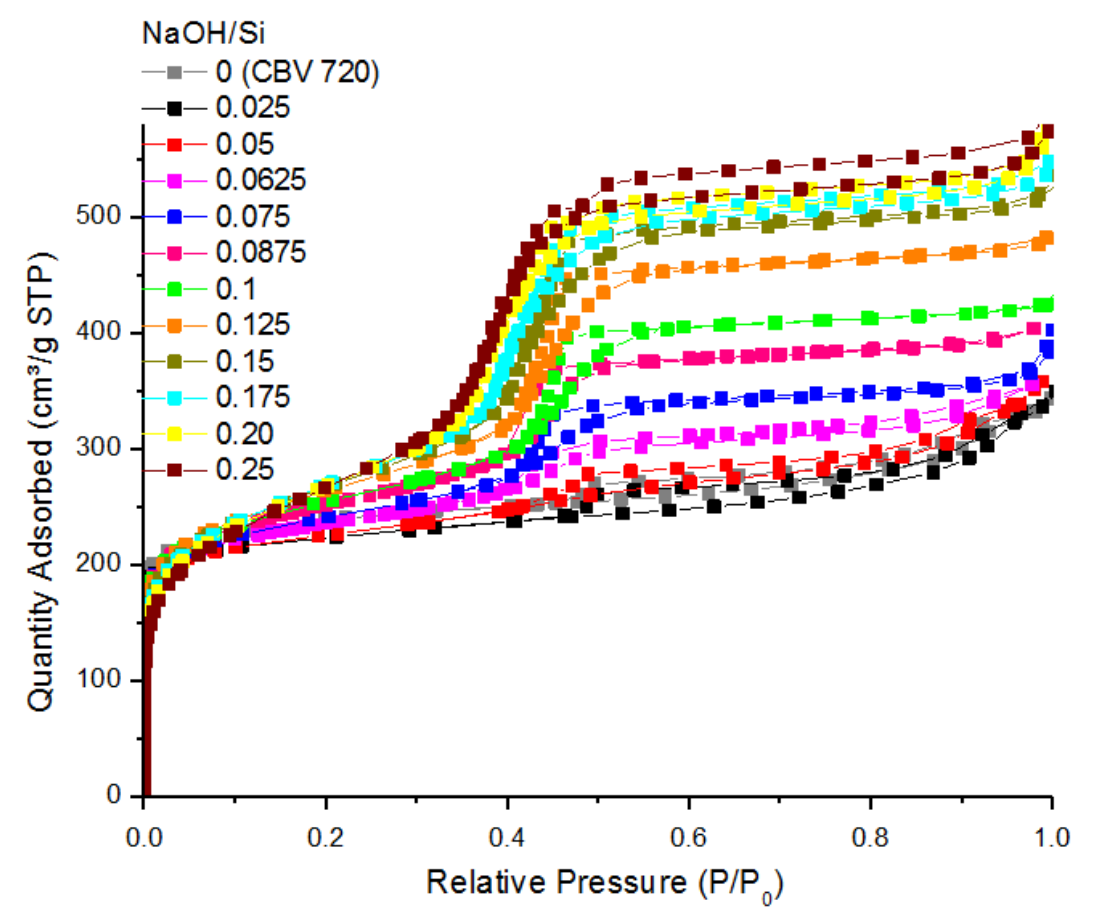




\section{Figure 5}

Required parameters are missing or incorrect.

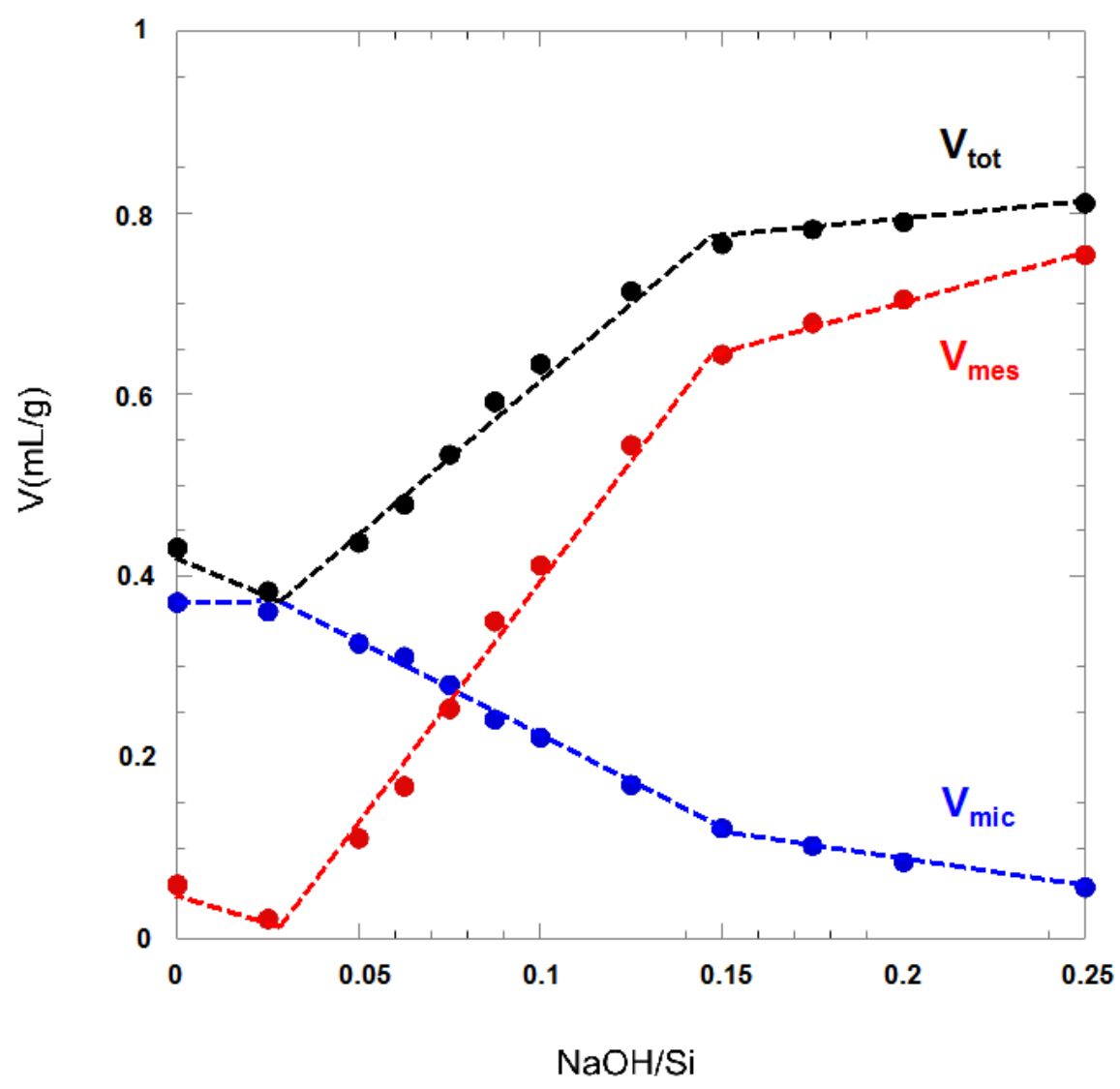


Figure 6

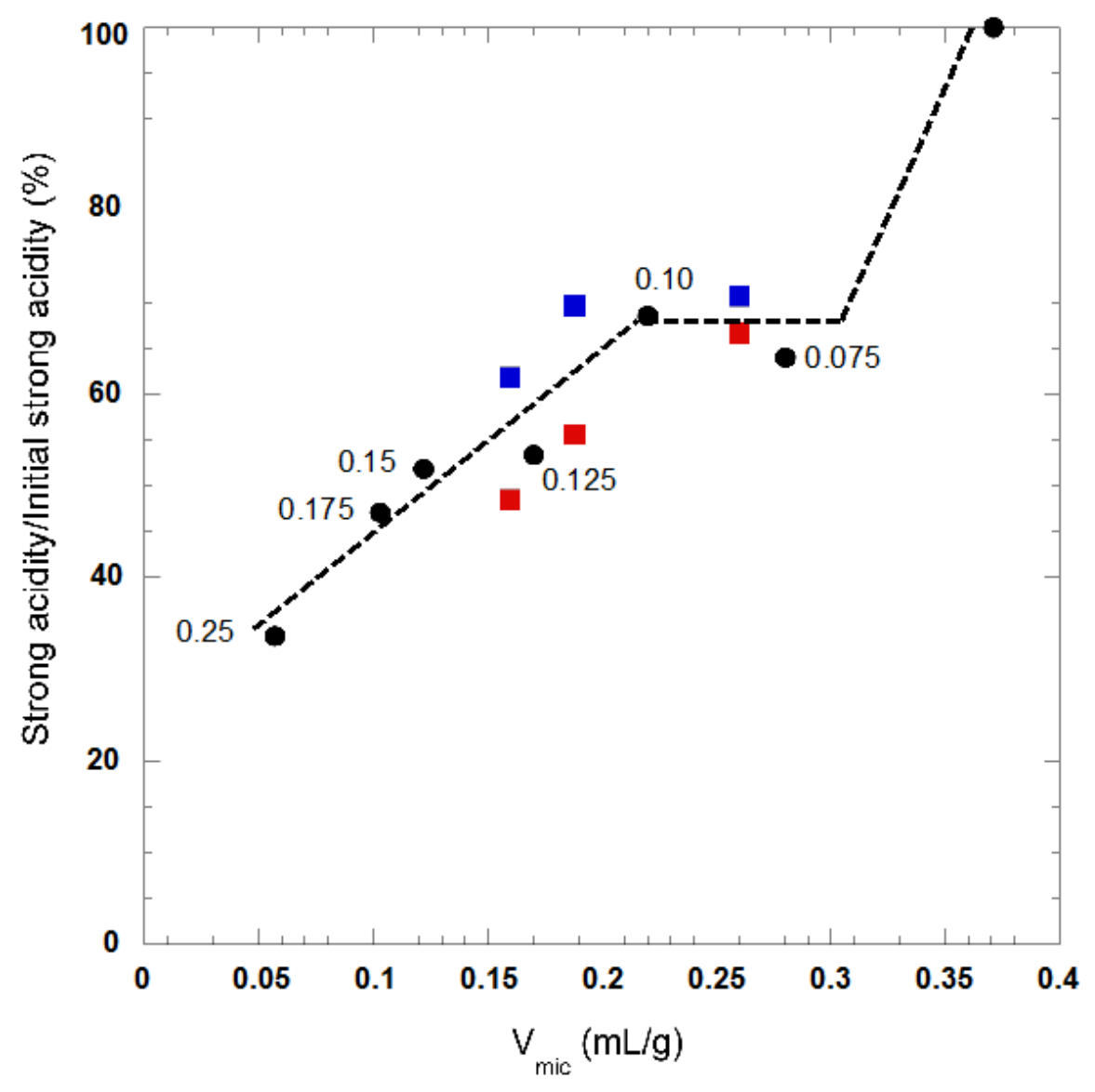




\section{Figure 7}
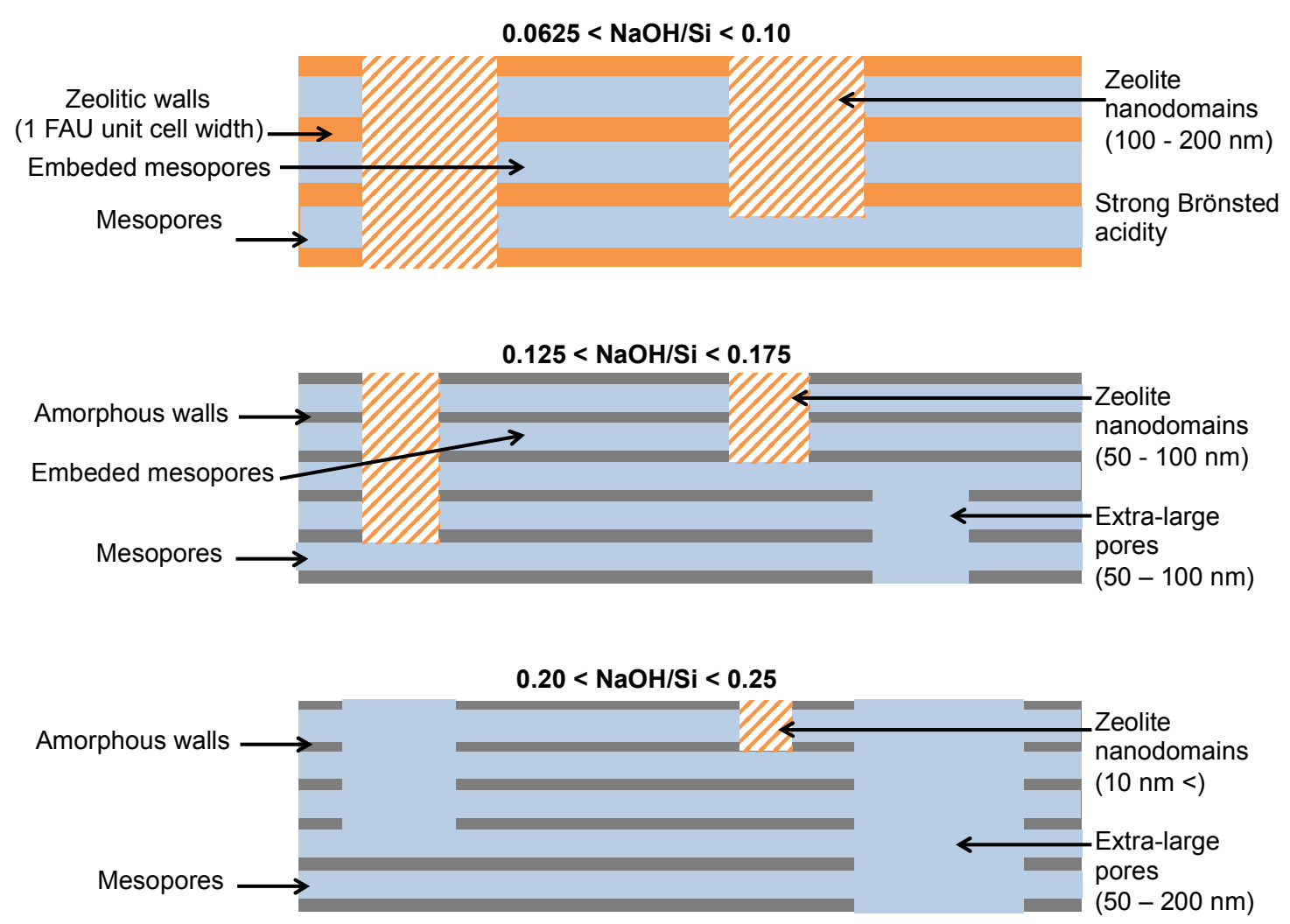


\section{Graphical Abstract}

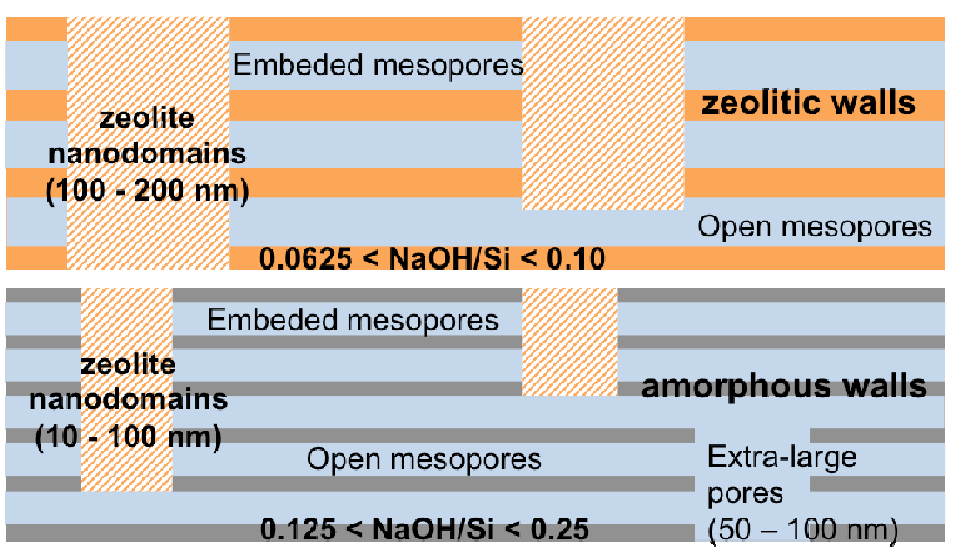

